\title{
Fabrication and characterization of dielectric ceramics using alumina and aluminosilicates
}

\section{(Fabricação e caracterização de cerâmicas dielétricas usando alumina e aluminossilicatos)}

\author{
R. S. Carvalho ${ }^{1}$, V.J.da Silva ${ }^{1}$, R. B.da Nóbrega ${ }^{2}$, H. L. Lira ${ }^{1}$, L. N. L. Santana ${ }^{1 *}$ \\ ${ }^{l}$ Federal University of Campina Grande, Materials Engineering Unit, Av. Aprígio Veloso 882, 58109-970, \\ Campina Grande, PB, Brazil \\ ${ }^{2}$ Federal University of Campina Grande, Department of Electrical Engineering, Campina Grande, PB, Brazil
}

\begin{abstract}
The aim was to study formulations containing aluminosilicate and alumina in order to obtain compositions with suitable properties to fabricate dielectric ceramic devices. Initially, the precursors were subjected to chemical, mineralogical and granulometric characterization. The formulations were defined and specimens were pressed (19.6 MPa) in shapes of disc and rectangular bar. Specimens were dried, heat-treated at 1400,1450 and $1500{ }^{\circ} \mathrm{C}$ and the mineralogical, morphological, physical, dielectric and mechanical properties were evaluated. The relative dielectric constant $\left(\varepsilon_{\mathrm{r}}\right)$ and loss tangent $(\tan \delta)$ were evaluated at $0.1,1,10$ and $100 \mathrm{kHz}$ at room temperature. The mullite was the major phase for the studied temperature range. Compositions with a higher content of fluxes showed lower porosity and better dielectric properties and flexural strength. Values of $\varepsilon_{\mathrm{r}}$ at $1 \mathrm{kHz}(\sim 3.5$ to 4.5$)$ were close to that of the mullite for the samples fired at $1400{ }^{\circ} \mathrm{C}$.
\end{abstract}

Keywords: aluminosilicates, mullite, dielectric properties.

\section{Resumo}

O objetivo foi estudar formulações contendo aluminossilicatos e alumina visando obter composições com propriedades adequadas para fabricação de componentes cerâmicos dielétricos. Inicialmente os precursores foram submetidos à caracterização química, mineralógica e granulométrica. As formulações foram definidas e os corpos de prova foram prensados (19,6 MPa) em forma de disco e barra retangular. Os espécimes foram secos, tratados termicamente entre 1400 e $1500{ }^{\circ} \mathrm{C}$ e as características mineralógica, morfológica, física, dielétricas e mecânicas foram avaliadas. A constante dielétrica relativa $\left(\varepsilon_{r}\right)$ e a tangente de perdas (tand) foram avaliadas a 0,1, 1, 10 e $100 \mathrm{kHz}$ à temperatura ambiente. A fase mulita foi majoritária para a faixa de temperatura estudada. Composições contendo maior teor de fundentes apresentaram menor porosidade e melhores propriedades dielétricas e resistência à flexão. Valores de constante dielétrica na frequência de $1 \mathrm{kHz}\left(\varepsilon_{r} \sim 3.5\right.$ a 4.5) foram próximos ao da mulita, para as composições sinterizadas a $1400{ }^{\circ} \mathrm{C}$.

Palavras-chave: aluminossilicatos, mulita, propriedades dielétricas.

\section{INTRODUCTION}

The use of ceramic materials for electrical applications has motivated researches aiming to improve the performance of these materials and reducing costs in the manufacturing process [1]. The ceramics produced for electrical applications have excellent dielectric and thermal properties that favor the use in both electrical insulation, such as insulators and transformer bushings, and electronic devices such as capacitors, playing an important role in the electronics industry [2]. Ceramics with a low dielectric constant are of great importance for microwave integrated circuits. For the substrate made with these materials, a signal delay can be

*lisiane.navarro@ufcg.edu.br

Dhttps://orcid.org/0000-0003-0235-8455 diminished in very high-frequency communication systems [3]. Among the ceramic materials, mullite and mullite-based composites are highlighted in the electronic industry due to their low values of dielectric constant and loss tangent, as well as low coefficient of thermal expansion, being applied as electronic substrate, microelectronic packaging, electrical insulators and ceramic capacitors [4-8].

Mullite is one of the phases formed when clays are heat-treated above $1000{ }^{\circ} \mathrm{C}$ [9]. Kaolin is a kaolinite-rich $\left(\mathrm{Al}_{2} \mathrm{O}_{3} \cdot 2 \mathrm{SiO}_{2} \cdot 2 \mathrm{H}_{2} \mathrm{O}\right)$ ore, which is one of the most used clays to synthesize mullite, however, it has a high amount of silica. Therefore, when a larger quantity of mullite is desired, it is necessary to add precursor sources rich in aluminum oxide to establish a higher ratio of $\mathrm{Al}_{2} \mathrm{O}_{3} / \mathrm{SiO}_{2}[10,11]$. Studies conducted by several researchers [12-18] had the purpose to obtain mullite from the sintering of clays and aluminum 
oxide as precursors, however, few studies were carried out emphasizing the dielectric properties of the ceramics obtained with these compositions. The production of dielectric ceramic components from kaolin has a high technological and economic viability due to the low-cost of the raw material and manufacturing process. In addition, the Brazilian Northeast region has mineral deposits that can be used for this purpose, expanding their use in more noble applications and providing cost reduction. Searching to contribute to current demand, this study aims to produce dielectric ceramic components from compositions containing kaolin, ball clay, and alumina.

\section{MATERIALS AND METHODS}

The following raw materials were used: kaolin, ball clay, and alumina. The raw materials were subjected to chemical characterization by X-ray fluorescence spectroscopy (Shimadzu, EDX-720). After the characterization, the sample compositions were defined (Table I), searching to achieve alumina/silica ratio close to mullite, which is one of the main phases that affect the dielectric properties. After defining the compositions, the powder mixtures were homogenized for 24 $\mathrm{h}$ and subsequently submitted to chemical and granulometric characterization. Particle size analysis was carried out in a granulometer (Cilas, 1064 LD). Specimens with disc (50x3 $\mathrm{mm})$ and rectangular bar $(50 \times 15 \times 5 \mathrm{~mm})$ shapes were formed by the pressing process, applying a pressure of $19.6 \mathrm{MPa}$ with presses from Servitech, SSN-EA and CT-335, respectively. Then, the pieces were dried at $110{ }^{\circ} \mathrm{C}$ and fired in an electric oven (Fortelab, ME-1700) at 1400,1450 and $1500{ }^{\circ} \mathrm{C}$, with a heating rate of $5{ }^{\circ} \mathrm{C} / \mathrm{min}$ and $60 \mathrm{~min}$ at the maximum temperature.

Table I - Formulation of raw materials (wt $\%$ ) used for each sample composition.

[Tabela I - Formulação de matérias-primas (\% em massa) utilizada para cada amostra.]

\begin{tabular}{ccccc}
\hline Sample & A & B & C & D \\
\hline Kaolin & 75 & 60 & 50 & 50 \\
Ball clay & - & 25 & 25 & 35 \\
Alumina & 25 & 15 & 25 & 15 \\
\hline
\end{tabular}

After sintering, the specimens were characterized by mineralogical, morphological, physical, dielectric and mechanical analysis. X-ray diffraction analysis was performed with a diffractometer (Shimadzu, XRD6000). The software Match! (Crystal Impact) and the JCPDS crystallographic files (PCPDFW in XRD6000 database) were used to identify the crystalline phases. The morphological analysis was performed using a scanning electron microscope (SEM, Shimadzu, SSX550). The length and width of mullite needles were measured with the ImageJ software. Apparent porosity was determined by the Archimedes' principle. The dielectric properties were evaluated at frequencies of $0.1,1,10$ and $100 \mathrm{kHz}$ at room temperature using a Schering bridge (Telmes, TR-9701). The relative dielectric constant $\left(\varepsilon_{\mathrm{r}}\right)$ and loss tangent $(\tan \delta)$ were calculated considering a parallel plate system:

$$
\begin{aligned}
& \varepsilon_{\mathrm{r}}=\frac{\mathrm{C} \cdot \mathrm{d}}{\varepsilon_{0} \cdot \mathrm{A}} \\
& \tan \delta=\frac{\varepsilon^{\prime \prime}}{\varepsilon^{\prime}}
\end{aligned}
$$

where $\mathrm{C}$ is the capacitance of the sample, $\mathrm{d}$ is the thickness of the sample, $\mathrm{A}$ is the effective area between the electrodes, and $\varepsilon_{0}$ is the permittivity of the free space $\left(8.85 \times 10^{-12} \mathrm{~F} / \mathrm{m}\right)$ [19]. The loss tangent $(\tan \delta)$ was directly given by the equipment. The flexural strength of the sintered specimens was determined by the three-point bending test, using a mechanical testing machine (Shimadzu, Autograph AG-X) with a maximum capacity of $50 \mathrm{kN}$.

\section{RESULTS AND DISCUSSION}

Table II shows the chemical composition of the samples studied. Samples A, B, C and D were predominantly constituted by silica $\left(\mathrm{SiO}_{2}\right)$ and alumina $\left(\mathrm{Al}_{2} \mathrm{O}_{3}\right)$ and the ratio of $\mathrm{Al}_{2} \mathrm{O}_{3} / \mathrm{SiO}_{2}$ was $1.27,1.15,1.45$ and 1.02 , respectively. These ratios favored the formation of the phase of interest (mullite) during the thermal treatments. Samples B, C, and D showed higher concentrations of flux oxides $\left(\mathrm{K}_{2} \mathrm{O}, \mathrm{Fe}_{2} \mathrm{O}_{3}\right.$, $\mathrm{MgO}$ ), which can accelerate the process of mullitization. Particle size analyses showed that the average particle diameter of the samples was $4.74 \mu \mathrm{m}$ for $\mathrm{A}, 4.23 \mu \mathrm{m}$ for $\mathrm{B}$, $4.10 \mu \mathrm{m}$ for $\mathrm{C}$ and $4.20 \mu \mathrm{m}$ for $\mathrm{D}$.

Table II - Chemical composition (wt\%) of samples A, B, C and D.

[Tabela II - Composição química (\% em massa) das amostras $A, B, C$ e D.]

\begin{tabular}{ccccc}
\hline Sample & $\mathrm{A}$ & $\mathrm{B}$ & $\mathrm{C}$ & $\mathrm{D}$ \\
\hline $\mathrm{SiO}_{2}$ & 43.5 & 44.2 & 39.0 & 46.9 \\
$\mathrm{Al}_{2} \mathrm{O}_{3}$ & 55.4 & 50.8 & 56.5 & 47.8 \\
$\mathrm{~K}_{2} \mathrm{O}$ & 0.7 & 0.9 & 1.5 & 1.1 \\
$\mathrm{Fe}_{2} \mathrm{O}_{3}$ & 0.3 & 1.6 & 0.9 & 1.9 \\
$\mathrm{MgO}$ & - & 1.5 & 1.4 & 1.4 \\
Other oxides & - & 1.0 & 0.7 & 0.9 \\
\hline
\end{tabular}

Fig. 1 presents the X-ray diffraction patterns of the samples fired at different temperatures. Samples A and C presented the phases mullite (JCPDS 79-1276) and $\alpha$-alumina (JCPDS 10-0173); sample A fired at $1400{ }^{\circ} \mathrm{C}$ also presented cristobalite (JCPDS 82-0512). For samples B and D, only the mullite phase was observed. In addition, for samples $A$ and $\mathrm{C}$, with the increase in sintering temperature, a significant reduction in the intensity of cristobalite and alumina peaks and an increase in the intensity of the mullite peaks were observed. The samples with higher amounts of flux oxides showed higher intensity mullite peaks, which may be related to the dissolution rate of $\mathrm{Al}_{2} \mathrm{O}_{3}$ and lower viscosity 
of the liquid phase during sintering, behavior also observed by other researchers [20]. The samples showed two mullite reflections at $2 \theta \sim 26^{\circ}$, which were attributed to the presence of orthorhombic mullite (secondary mullite), obtained from aluminosilicates [15]. The amorphous phase located in the $2 \theta$ range from $15^{\circ}$ to $30^{\circ}$ for all samples was attributed to the partial decomposition of quartz.

In Table III, it is possible to observe the quantification
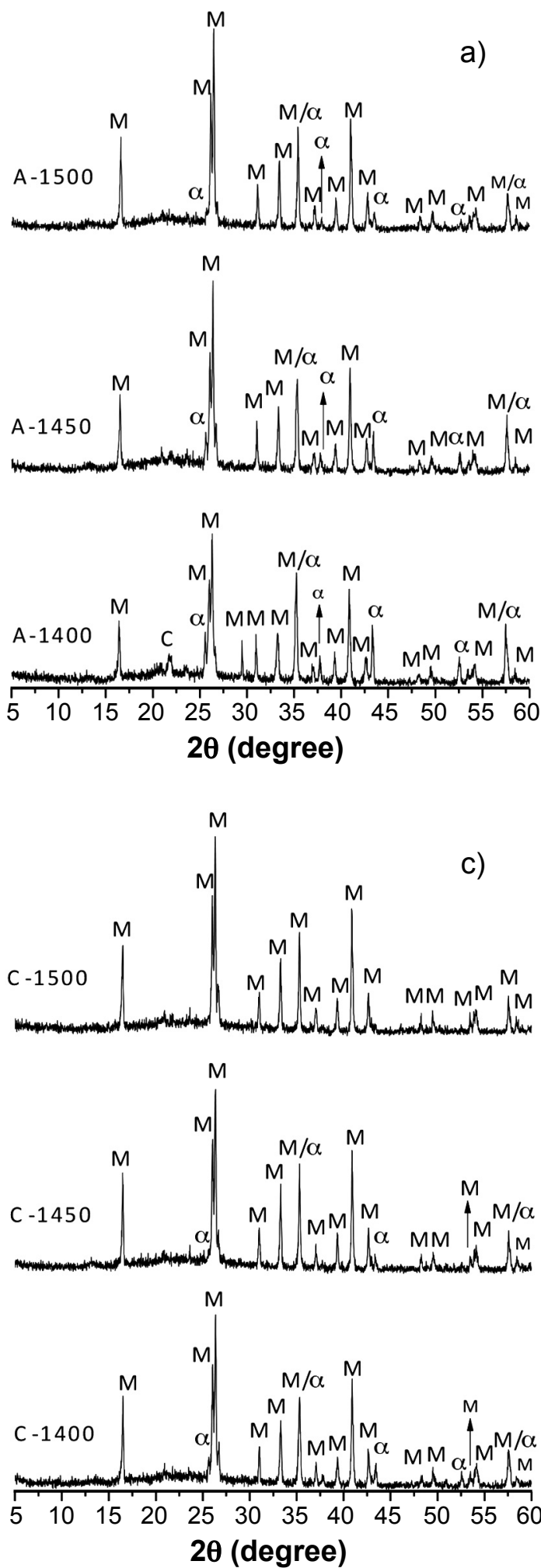
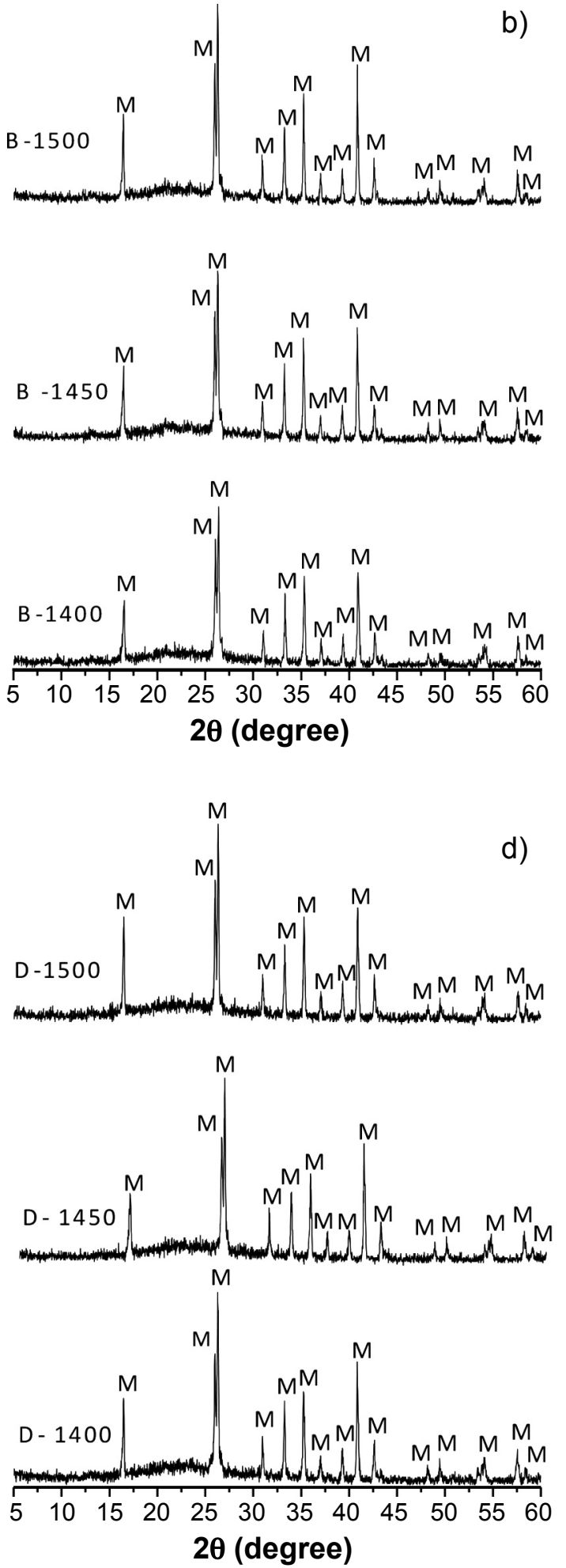

Figure 1: X-ray diffraction patterns of samples A (a), B (b), C (c) and D (d) sintered at 1400, 1450 and $1500{ }^{\circ} \mathrm{C} . \mathrm{M}-$ mullite; $\alpha-\alpha$-alumina; $\mathrm{C}$ - cristobalite.

[Figura 1: Espectros de difração de raios X das amostras A (a), B (b), C (c) e D (d) sinterizadas a 1400, 1450 e $1500{ }^{\circ} \mathrm{C} . M-$ mulita; $\alpha$ $\alpha$-alumina; $C$ - cristobalita.] 
of the crystalline phases formed after the heat treatment of the samples. In general, it was observed that the

Table III - Fractions of crystalline phases (mullite, cristobalite, and $\alpha$-alumina) and degree of crystallinity of the samples (wt\%) sintered at 1400,1450 and $1500{ }^{\circ} \mathrm{C}$.

[Tabela III - Frações de fases cristalinas (mulita, cristobalita e a-alumina) e grau de cristalinidade das amostras (\% em massa) sinterizadas a 1400,1450 e $1500{ }^{\circ} \mathrm{C}$.]

\begin{tabular}{ccccc}
\hline Sample & Mullite & $\alpha-\mathrm{Al}_{2} \mathrm{O}_{3}$ & Cristobalite & Crystallinity \\
\hline A-1400 & 64.3 & 21.9 & 1.2 & 87.4 \\
$\mathrm{~B}-1400$ & 70.5 & - & - & 70.5 \\
$\mathrm{C}-1400$ & 72.1 & 10.4 & - & 82.6 \\
$\mathrm{D}-1400$ & 76.3 & - & - & 76.3 \\
$\mathrm{~A}-1450$ & 67.6 & 21.0 & - & 88.7 \\
$\mathrm{~B}-1450$ & 73.6 & - & - & 73.6 \\
$\mathrm{C}-1450$ & 72.0 & 4.0 & - & 76.1 \\
$\mathrm{D}-1450$ & 71.8 & - & - & 71.8 \\
$\mathrm{~A}-1500$ & 75.0 & 6.6 & - & 81.6 \\
$\mathrm{~B}-1500$ & 82.6 & - & - & 82.6 \\
$\mathrm{C}-1500$ & 88.2 & - & - & 88.2 \\
$\mathrm{D}-1500$ & 73.7 & - & - & 73.7 \\
\hline
\end{tabular}

contents of the mullite phase increased with an increase in the firing temperature. According to [21], the mullite is obtained by the reaction between silica and alumina at high temperatures, because with the increase of the temperature occurs the interdiffusion of the ions in the interfaces between the particles of alumina and silica. When submitted to temperatures higher than $1440{ }^{\circ} \mathrm{C}$, higher content of aluminum ions from alumina is released to the system, allowing silicon ions to be redissolved until the stoichiometric proportion of the mullite is reached. Sample A presented the cristobalite phase when fired at $1400{ }^{\circ} \mathrm{C}$ and with the temperature increase it was observed that this phase disappeared, while the $\alpha$-alumina was considerably reduced. For samples B and D that presented lower alumina content in its composition (Table I), when sintered at the temperature range studied, it was identified only the crystalline phase of mullite and vitreous phase; similar behavior was observed by other researchers [22]. For sample $\mathrm{C}$, it was observed the presence of the alumina phase up to $1450{ }^{\circ} \mathrm{C}$, which disappeared with the increase of firing temperature up to $1500{ }^{\circ} \mathrm{C}$, thus increasing the amount of mullite.

Fig. 2 presents micrographs of the fracture surface of samples A, B, C and D sintered at $1450{ }^{\circ} \mathrm{C}$. It was possible to identify grains with needle morphology in all samples, characteristic of the secondary mullite grains. The presence of a vitreous phase was also observed. Table IV shows the
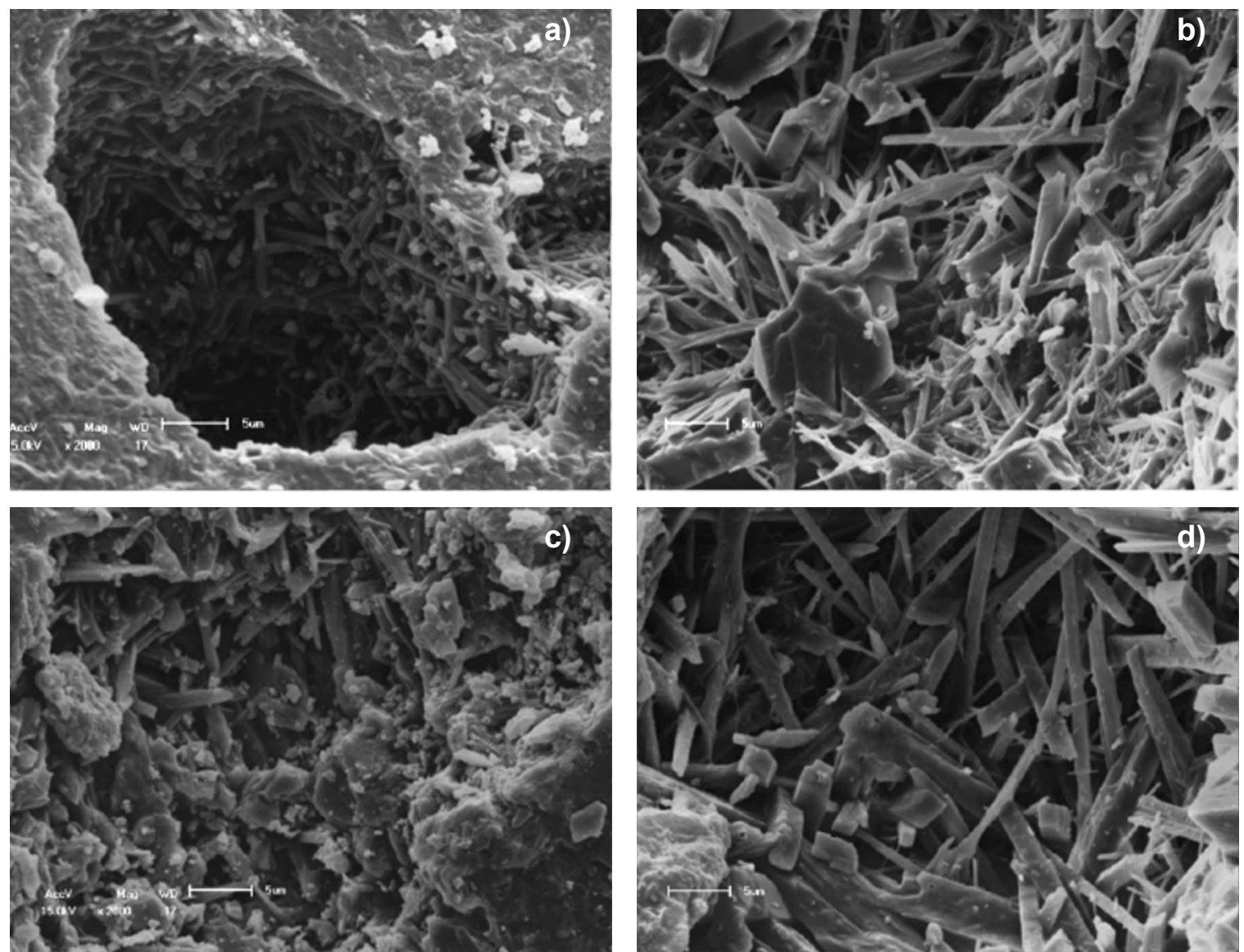

Figure 2: SEM micrographs of fracture surface of the samples A (a), B (b), C (c), and D (d) sintered at $1450{ }^{\circ} \mathrm{C}$.

[Figura 2: Micrografias de MEV de superfície de fratura das amostras $A(a), B(b), C(c)$ e $D(d)$ sinterizadas a $1450{ }^{\circ} \mathrm{C}$.] 
average length and width of the mullite grains. Samples B, $\mathrm{C}$, and D, which had higher contents of flux oxides (Table II), mainly iron oxide, presented mullite grains with larger sizes. These samples also presented small average widths, which interfered in the nucleation and growth processes of the mullite grains. Smaller particle size suggests larger surface area and greater reactivity, favoring the process of dissolution of aluminum and silicon ions, which provides greater mullite grains through the dissolution-precipitation mechanism. Some researchers [23] related the process of mullitization with the particle size of the powders.

Table IV - Dimensions of mullite grains. [Tabela IV - Dimensões dos grãos de mulita.]

\begin{tabular}{ccc}
\hline Sample & Length $(\mu \mathrm{m})$ & Width $(\mu \mathrm{m})$ \\
\hline A-1450 & 4.4 & 0.4 \\
B-1450 & 8.8 & 0.5 \\
C-1450 & 6.2 & 0.7 \\
D-1450 & 10.3 & 0.9 \\
\hline
\end{tabular}

Table V shows the values of the porosity of the samples after heat treatment. It was observed that the samples containing a higher content of flux oxides presented lower porosity for all temperatures analyzed. The samples A and $\mathrm{C}$ presented higher porosity at $1400{ }^{\circ} \mathrm{C}$ and more significant porosity reduction with the increase of firing temperature to $1500{ }^{\circ} \mathrm{C}$. These two samples, which presented a higher $\mathrm{Al}_{2} \mathrm{O}_{3} / \mathrm{SiO}_{2}$ ratio and smaller $\mathrm{Fe}_{2} \mathrm{O}_{3}$ content, needed higher temperature $\left(1500^{\circ} \mathrm{C}\right)$ to increase the densification during the sintering process. For samples B and D, there was an increase in porosity when the specimens were fired at $1500^{\circ} \mathrm{C}$, the same behavior also observed by other researchers [2]. This effect may be related to the transformations and intensification of the formed phases; at this temperature, only the mullite phase was observed (Fig. 1) and probably alumina reacted with silica forming elongated mullite grains. Another fact that may also justify the increase in porosity is the higher contents of iron oxide (Table II) in these samples, since the $\mathrm{Fe}_{2} \mathrm{O}_{3}$ can change to $\mathrm{Fe}_{3} \mathrm{O}_{4}$ and generate $\mathrm{O}_{2}$ at elevated temperatures. Other researchers [24], who also investigated the thermal behavior of kaolin-containing formulations, related the increase in pore size in this temperature range with this reaction.

Fig. 3 shows the values of dielectric constant and loss

Table V - Porosity (\%) of the samples sintered at different temperatures.

[Tabela V - Porosidade (\%) das amostras sinterizadas em diferentes temperaturas.]

\begin{tabular}{cccc}
\hline Sample & $1400{ }^{\circ} \mathrm{C}$ & $1450{ }^{\circ} \mathrm{C}$ & $1500{ }^{\circ} \mathrm{C}$ \\
\hline A & $7.5 \pm 0.6$ & $7.5 \pm 0.1$ & $5.5 \pm 0.4$ \\
B & $2.1 \pm 0.6$ & $2.3 \pm 0.1$ & $3.6 \pm 0.2$ \\
C & $6.5 \pm 0.8$ & $2.5 \pm 0.2$ & $2.5 \pm 0.6$ \\
D & $1.8 \pm 0.1$ & $2.2 \pm 0.7$ & $4.0 \pm 0.8$ \\
\hline
\end{tabular}

tangent at the frequencies of $0.1,1,10$ and $100 \mathrm{kHz}$. The values of the dielectric constant $\left(\varepsilon_{\mathrm{r}}\right)$ reduced with the increase in frequency and were lower for the samples fired at higher temperatures. It stood out for samples B and D that for the frequency above $1 \mathrm{kHz}$ the loss tangent tended to stabilize. According to [25], the low-frequency behavior can be attributed to the various polarizations (electronic, atomic, ionic and interfacial), however, for the higher frequencies, it may be related to electronic polarization. The electronic polarizations are oriented with the electric field in the lowfrequency range, but at a higher frequency, the individual internal dipoles that contribute to the dielectric constant cannot move instantaneously [26]. Some researchers [8] related the reduction of dielectric constant for mullite composites with the electronic polarization and accumulated energy in the interfaces of the phases present in the system. It was observed that the values of dielectric constant were lower for the samples fired at higher temperatures, behavior that was probably related to the phases and their quantities, as well as to the size of the grains. According to [27], the dielectric behavior of porcelain is a variable that depends on the quantity of the phases of mullite, quartz, cristobalite and vitreous phase. They observed a parabolic behavior; the dielectric constant value increased to a maximum value and then reduced with the increase in the amount of mullite and quartz; however, for the cristobalite and vitreous phase, they observed opposite behavior, highlighting the complexity of the influence of the phases formed on the dielectric properties. It is also emphasized that the boundaries between the mullite grains are considered pathways that allow the dissipation of the current in the sample [27]. In Fig. 3, it is verified that the highest values of $\varepsilon_{\mathrm{r}}$ were observed at the frequency of $0.1 \mathrm{kHz}$. The samples sintered at $1400{ }^{\circ} \mathrm{C}$ showed dielectric constants in the range of 3.5 to 4.5 at $1 \mathrm{kHz}$. According to the literature [28], mullite presents a dielectric constant in the range of 6 to 7 at the frequency of $1 \mathrm{kHz}$. The analysis of the loss tangent ( $\tan \delta$ ) evidenced a tendency of reduction with the increase in frequency, behavior also observed by other researchers [5]. For samples A, B and C, making an analysis of the loss tangent for the frequencies above 0.1 $\mathrm{kHz}$, it was observed that the smallest values were found for the samples sintered at 1450 and $1500{ }^{\circ} \mathrm{C}$. For sample D, the smallest tan $\delta$ values were observed at $1400{ }^{\circ} \mathrm{C}$; this behavior may be related to a greater amount of mullite and a smaller amount of vitreous phase. The lowest values were observed at the frequency of $100 \mathrm{kHz}$ for all specimens, which can be attributed to limited dipole responses [4, 29].

Fig. 4 shows the values of dielectric constant $\left(\varepsilon_{\mathrm{r}}\right)$ and loss tangent $(\tan \delta)$ as a function of porosity, at the frequency of $0.1,1,10$ and $100 \mathrm{kHz}$ for the studied samples. In general, by analyzing the porosity and frequency, lower dielectric constant values were observed for the most porous specimens when submitted to higher frequencies. This effect was due to the contribution of the pores to the value of dielectric constant; the air presents dielectric constant of $\sim 1.0$ [8], lower than those of the crystalline and amorphous phases present in the microstructure. The highest dielectric constant 

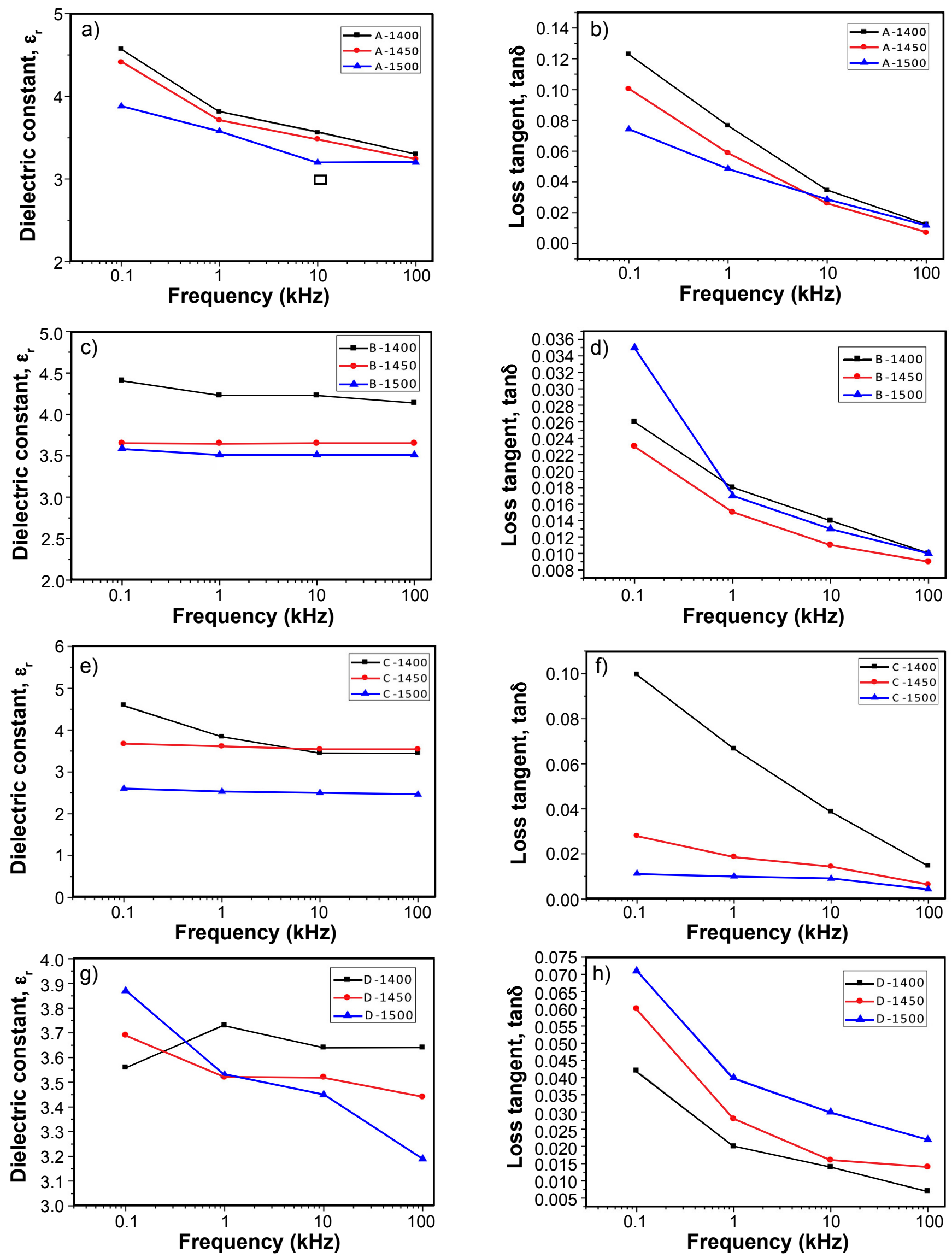

Figure 3: Dielectric constant (a,c,e,g) and loss tangent (b,d,f,h) as a function of frequency for the samples: a,b) A; c,d) B; e,f) C; and g,h) D. [Figura 3: Constante dielétrica $(a, c, e, g)$ e tangente de perdas $(b, d, f, h)$ em função da frequência das amostras: $a, b) A ; c, d) B ; e, f) C ; e g, h) D$. 

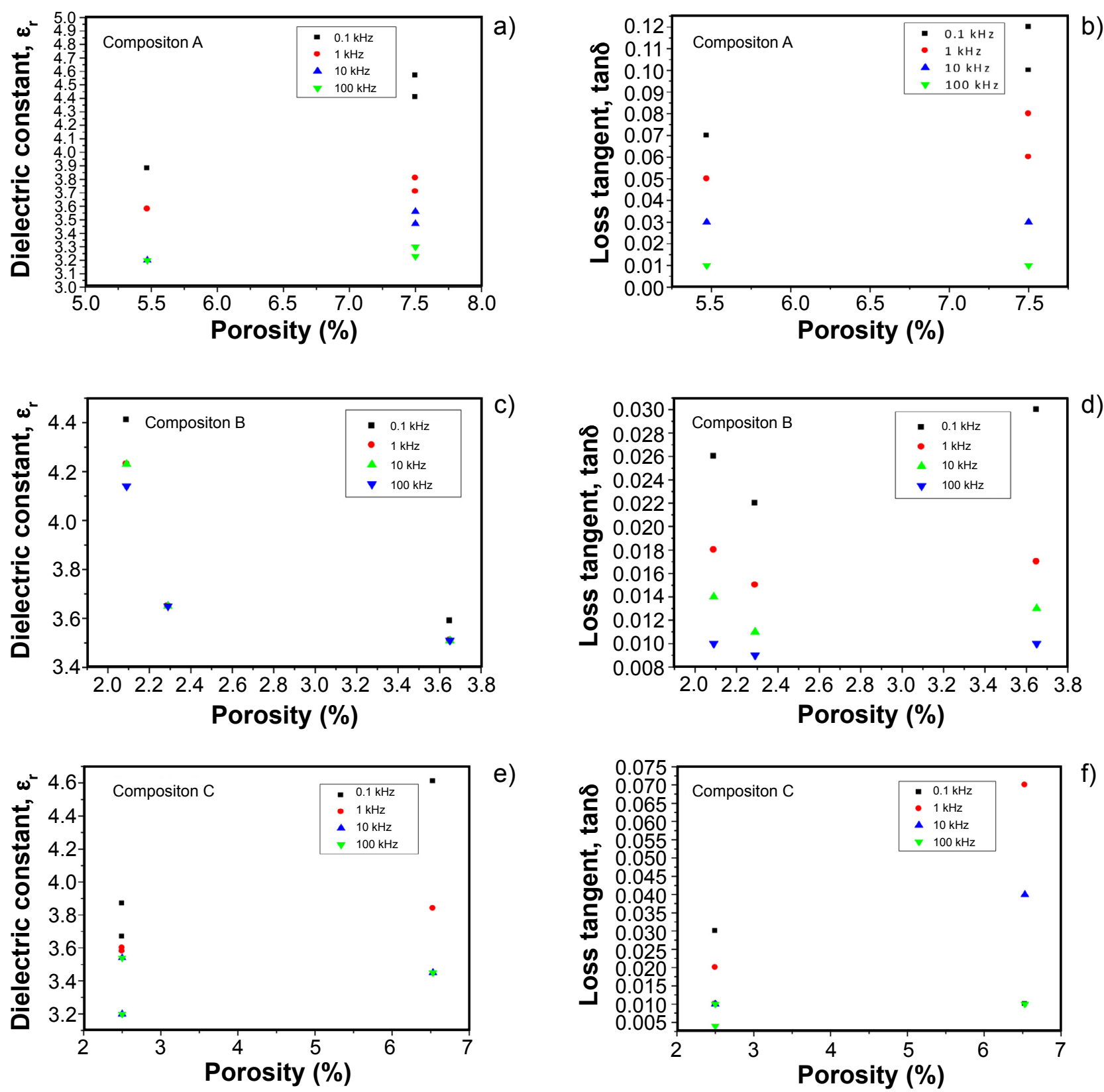

e)

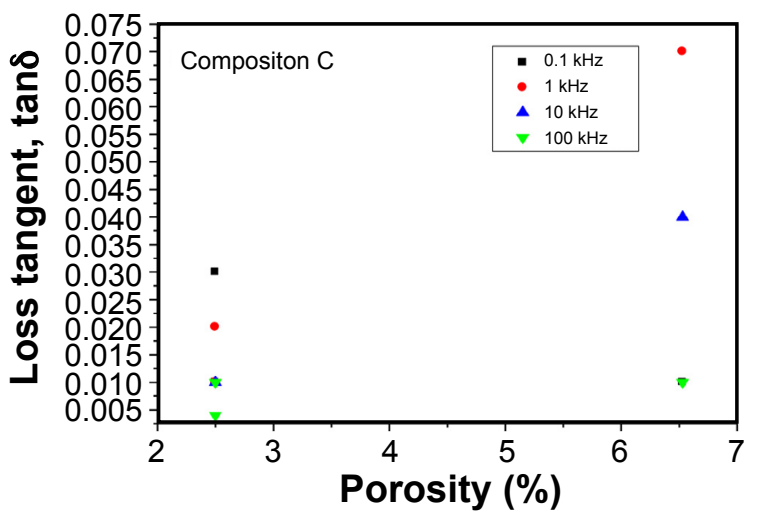

f)
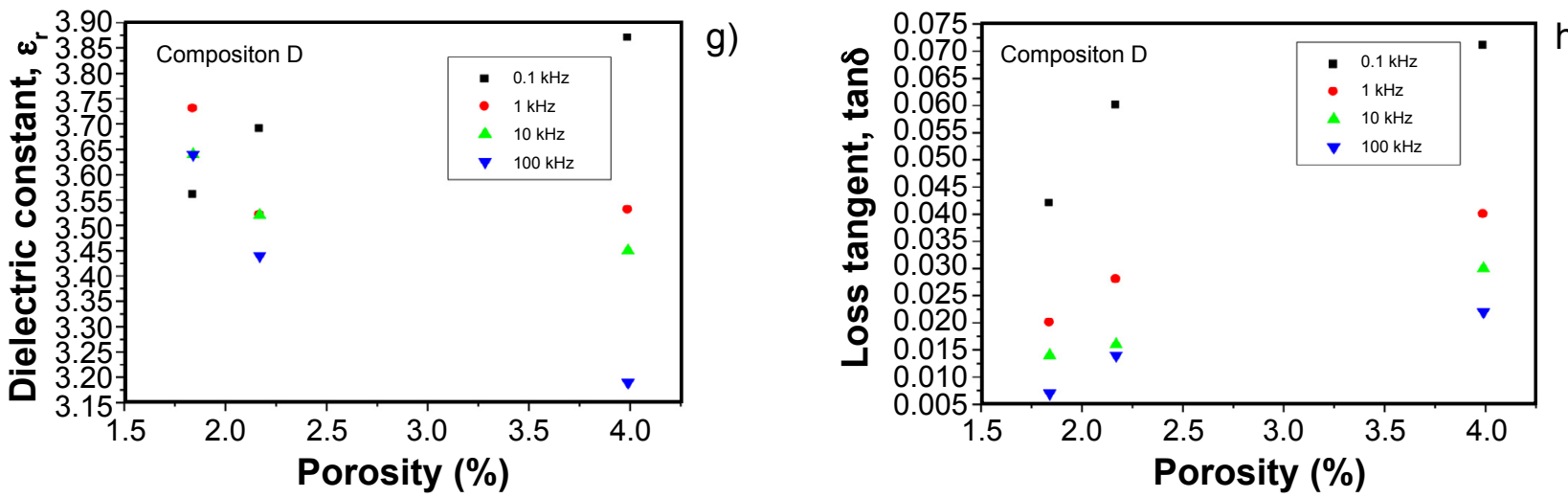

Figure 4: Dielectric constant (a,c,e,g) and loss tangent (b,d,f,h) as a function of porosity at frequency of $0.1,1,10$ and $100 \mathrm{kHz}$ for the samples: a,b) A; c,d) B; e,f) C; and g,h) D.

[Figura 4: Constante dielétrica (a,c,e,g) e tangente de perdas $(b, d, f, h)$ em função da porosidade nas frequências de $0,1,1,10$ e $100 \mathrm{kHz}$ das amostras: $a, b) A$; $c, d) B$; $e, f) C$; e g,h) D.] 
values at low frequencies were observed for samples $\mathrm{A}$ and $\mathrm{C}$, which presented mullite and alumina as the main crystalline phases, behavior also observed by other researchers [4] who analyzed dielectric properties of mullite and alumina composites. According to [29], at low frequencies when an electric field is applied on the specimens, the charge carriers can move and accumulate at the interface between the phases present in the matrix, because of the difference in electrical conductivity. Regarding the loss tangent, similar behavior to the dielectric constant was observed, highlighting the highest values for composition A, which had porosity in the range of $5.5 \%$ to $7.5 \%$. Correlating with other microstructural aspects, it can be highlighted the size of mullite grains, the presence of alumina in higher quantity and a high degree of crystallinity, factors that also favored the increase of the loss tangent. Sample A presented the smallest grain size (Table IV) and the grain boundaries are considered to be the paths that allow dissipation of current in the sample. The number and length of such boundaries or continuous paths, also called the mean free path, control the uninterrupted flow of current through the sample in a manner so that longer boundaries constitute longer mean free path resulting in more current and dielectric loss [27].

Table VI shows the values of flexural strength for the sintered samples. In general, the best results were observed for the samples fired at $1500{ }^{\circ} \mathrm{C}$, which may be related to the higher quantity of the mullite phase formed. The improvement in the mechanical resistance may be related to the difference in thermal expansion coefficient between the vitreous matrix and the dispersed particles (mullite) that can generate compressive stresses in the vitreous matrix; additionally, the presence of dispersed particles may interfere with the propagation path of the cracks [30]. In general, the lower results were observed for the specimens obtained with the composition A, which presented the smallest amount of mullite, higher porosity, and smaller grain size, which according to [31] should present adequate size to favor interlacing, which affects the mechanical resistance. It was also observed that the specimens obtained with compositions $\mathrm{B}$ and D presented the best results for sintering at 1400 and $1450{ }^{\circ} \mathrm{C}$, which may be related mainly to the lower porosity and the presence of the mullite phase in higher quantity (Table III). The specimens obtained with composition $\mathrm{C}$ presented the lowest strength values for the sintering at $1450{ }^{\circ} \mathrm{C}$; this behavior may be related to the highest $\mathrm{K}_{2} \mathrm{O}$ content (Table II)

Table VI - Flexural strength (MPa) of the samples sintered at different temperatures.

[Tabela VI - Resistência à flexão (MPa) das amostras sinterizadas em diferentes temperaturas.]

\begin{tabular}{cccc}
\hline Sample & $1400{ }^{\circ} \mathrm{C}$ & $1450{ }^{\circ} \mathrm{C}$ & $1500{ }^{\circ} \mathrm{C}$ \\
\hline A & $38.0 \pm 2.0$ & $35.8 \pm 2.4$ & $40.2 \pm 3.2$ \\
B & $51.8 \pm 8.9$ & $50.0 \pm 9.5$ & $66.1 \pm 6.3$ \\
C & $41.9 \pm 2.7$ & $35.7 \pm 2.3$ & $45.2 \pm 5.1$ \\
D & $45.7 \pm 4.8$ & $46.2 \pm 5.1$ & $47.9 \pm 5.5$ \\
\hline
\end{tabular}

that favored the formation of vitreous phase. In a study [32] conducted to obtain mullite using kaolin residue and alumina as precursors fired at $1450{ }^{\circ} \mathrm{C}$, the flexural strength obtained was close to those obtained in this study for the sintering at $1400{ }^{\circ} \mathrm{C}$. For composition D, a significant increase in the strength was not observed for specimens fired at $1500{ }^{\circ} \mathrm{C}$; this sample presented higher content of flux oxides, which may have favored grain growth, with needle morphology. At high temperatures, the mullite needles coarsen, leading to a smaller number of larger needles. Larger needles do not interlock as efficiently as smaller ones, and a decrease in strength results [31].

\section{CONCLUSIONS}

According to the mineralogical and morphological analysis, the major crystalline phase formed was mullite and grains with a characteristic of needles in all compositions sintered between 1400 and $1500{ }^{\circ} \mathrm{C}$. Samples containing a higher content of flux oxides presented lower porosity, contributing directly to reduce dielectric constant and loss tangent $(\tan \delta)$ and increase flexural strength. The samples sintered at $1400{ }^{\circ} \mathrm{C}$ showed dielectric constant in the range of 3.5 to 4.5 at $1 \mathrm{kHz}$, close to the value of the mullite. Low dielectric losses $(\tan \delta \sim 0.01$ ) were observed at the frequency of $100 \mathrm{kHz}$. Therefore, the compositions containing kaolin, ball clay and alumina (samples B, C, and D) have the potential for electronic applications as integrated circuit substrates for microwave devices, being a viable alternative due to the low cost of raw materials.

\section{ACKNOWLEDGMENTS}

The authors thank CNPq (Brazil) for the financial support and to Professor Dr. Edson Guedes from Electrical Engineering Department, Federal University of Campina Grande, Brazil, for the dielectric characterizations.

\section{REFERENCES}

[1] J.M. Amigo, J.V. Clausell, V. Esteve, J.M. Delgado, M.M. Reventos, L.E. Ochando, T. Debaerdemaeker, F. Marti, J. Eur. Ceram. Soc. 24 (2004) 75.

[2] S. Kasrani, A. Harabi, S.-E. Barama, L. Foughali, M.T. Benhassine, D.M. Aldhayan, Cerâmica 62, 364 (2016) 405. [3] D. Szwagierczak, B. Synkiewicz, J. Kulawik, Ceram. Int. 44 (2018) 14495.

[4] A. Kool, P. Thakur, B. Bagchi, N.A. Hoque, S. Das, Appl. Clay Sci. 114 (2015) 349.

[5] J.P.F. Grilo, H.P.A. Alves, A.J.M. Araújo, R.M. Andrade, R.P.S. Dutra, D.A. Macedo, Cerâmica 65, 373 (2019) 117.

[6] N.S. Mehta, P.K. Sahu, P. Tripathi, R. Pyare, M.R. Majhi, Bol. Soc. Esp. Ceram. V. 57 (2018) 151.

[7] A. Purohit, S. Chander, A. Hameed, P. Singh, M. Dhaka, Mater. Chem. Phys. 181 (2016) 359.

[8] V.J. da Silva, E.P. de Almeida, W.P. Gonçalves, R.B. da Nóbrega, G.A. Neves, H.L. Lira, R.R. Menezes, L.N.L. 
Santana, Ceram. Int. 45 (2019) 4692.

[9] A. Khalfaoui, M. Hajjaji, Appl. Clay Sci. 45 (2009) 83.

[10] M. Sanad, M. Rashad, E. Abdel-Aal, M. El-Shahat, Ceram. Int. 39 (2013) 1547.

[11] H. Schneider, J. Schreuer, B. Hildmann, J. Eur. Ceram. Soc. 28 (2008) 329.

[12] M. Sainz, F. Serrano, J. Amigo, J. Bastida, A. Caballero, J. Eur. Ceram. Soc. 20 (2000) 403.

[13] R. Donelson, G. Paul, F. Ciacchi, S. Badwal, J. Membr. Sci. 463 (2014) 126.

[14] L. Santana, J. Gomes, G. Neves, H. Lira, R. Menezes, A. Segadães, Appl. Clay Sci. 87 (2014) 28.

[15] H.P. Alves, J.B. Silva, L.F. Campos, S.M. Torres, R.P. Dutra, D.A. Macedo, Ceram. Int. 42 (2016) 19086.

[16] S.G. Medeiros, R.P.S. Dutra, J.P.F. Grilo, A.E. Martinelli, C.A. Paskocimas, D.A. Macedo, Cerâmica 62, 363 (2016) 266.

[17] F. Chargui, M. Hamidouche, H. Belhouchet, Y. Jorand, R. Doufnoune, G. Fantozzi, Bol. Soc. Esp. Ceram. V. 57 (2018) 169.

[18] J. Ma, F. Ye, B. Zhang, Y. Jin, C. Yang, J. Ding, H. Zhang, Q. Liu, Ceram. Int. 44 (2018) 13320.

[19] J. Almiral Mesa, Temas de ingenieria electrica, Ed. Félix Varela, La Habana (2009) 623.
[20] X. Xu, X. Lao, J. Wu, Y. Zhang, X. Xu, K. Li, Appl. Clay Sci. 115 (2015) 76.

[21] M.V.M. Magliano, V.C. Pandolfelli, Cerâmica 56, 340 (2010) 368 .

[22] I. Khorchani, O. Hafef, J.J. Reinosa, A. Matoussi, J. Fernandez, Mater. Chem. Phys. 212 (2018) 187.

[23] J. Temuujin, K. Okada, K. MacKenzie, J. Eur. Ceram. Soc. 18 (1998) 831.

[24] C. Chen, W. Tuan, Ceram. Int. 27 (2001) 795.

[25] D. Roy, B. Bagchi, S. Das, P. Nandy, Mater. Chem. Phys. 138 (2013) 375.

[26] B.K. Paul, K. Haldar, D. Roy, B. Bagchi, A. Bhattacharya, S. Das, J. Adv. Ceram. 3 (2014) 278.

[27] S. Chaudhuri, P. Sarkar, Ceram. Int. 26 (2000) 865.

[28] N. Lertcumfu, K. Pengpat, S. Eitssayeam, T. Tunkasiri, G. Rujijanagul, Ceram. Int. 41, Sup. 1 (2015) S447.

[29] P. Thakur, A. Kool, B. Bagchi, S. Das, P. Nandy, Appl. Clay Sci. 99 (2014) 149.

[30] L. Carbajal, F. Rubio-Marcos, M. Bengochea, J. Fernandez, J. Eur. Ceram. Soc. 27 (2007) 4065.

[31] A. Tucci, L. Esposito, L. Malmusi, E. Rambaldi, J. Eur. Ceram. Soc. 27 (2007) 1875.

[32] R.R. Menezes, M.F. Oliveira, L.N.L. Santana, G.A. Neves, H.C. Ferreira, Cerâmica 53, 328 (2007) 388.

(Rec. 13/06/2019, Rev. 05/09/2019, Ac. 12/09/2019) 